\title{
A minimally invasive technique for primary tooth extraction: a case report
}

\author{
Técnica minimamente invasiva para exodontia \\ de dente decíduo: relato de caso
}

\author{
Gabriela Oliveira BORGO1 iD https://orcid.org/0000-0001-8965-1755 \\ Karina Guedes de SOUSA ${ }^{1}$ iD https://orcid.org/0000-0003-3784-9537 \\ Kelly Maria Silva MOREIRA' ${ }^{\text {ID }}$ https://orcid.org/0000-0002-1137-3908 \\ Regina Maria PUPPIN-RONTANI ${ }^{1}$ iD https://orcid.org/0000-0002-1218-5159
}

\begin{abstract}
Root resorption is characterized by the loss of cementum and / or dentin from the tooth root as a result of internal or external odontoclastic action. This case reports a premature cervical root resorption of deciduous teeth in an 8-year-old boy. Large root resorption on the mesial faces of the maxillary and mandibular right and left deciduous canines (teeth \#53, \#63, \#73 and \#83), with asymptomatic pulp involvement, was detected during routine radiographic examination for orthodontic planning. The patient was managed with extraction of the affected teeth using two different techniques: conventional and alternative. The conventional technique, forceps, was used for the maxillary and mandibular left canines (teeth \#63 and \#73). And alternative technique using the periotome device, usually required for extraction during dental implant surgery, was used for the maxillary and mandibular right canines (teeth \#53 and \#83). The periotome device showed to be an alternative to improve pediatric surgery due to better patient behavior and healing, and to reduced procedure length.
\end{abstract}

Indexing terms: Root resorption. Tooth, deciduous. Tooth extraction.

\section{RESUMO}

A reabsorção radicular é caracterizada pela perda de cemento elou dentina da raiz do dente como resultado de uma ação odontoclástica interna ou externa. Este caso relata uma reabsorção cervical precoce da raiz dos dentes decíduos numa criança de 8 anos de idade. Grande reabsorção radicular nas faces mesiais dos caninos decíduos superiores e inferiores direito e esquerdo (dentes \#53, \#63, \#73 e \#83), com envolvimento assintomático da polpa, foi detectada durante o exame radiográfico de rotina para planejamento ortodôntico. O paciente foi submetido à exodontia dos dentes comprometidos, utilizando duas técnicas distintas: convencional e alternativa. A técnica convencional, fórceps, foi escolhida para os caninos esquerdo maxilar e mandibular (dentes $n .{ }^{\circ} 63$ e $n .^{\circ} 73$ ). E a técnica alternativa utilizando o instrumento periótomo, normalmente necessário para exodontias prévias a cirurgia de implantes dentários, foi utilizada para os caninos direito maxilar e mandibular (dentes $n .^{\circ} 53$ e $n .^{\circ} 83$ ). O instrumento periótomo demonstrou ser uma alternativa para melhorar a cirurgia pediátrica devido ao melhor comportamento e cicatrização do paciente, e à redução da duração do procedimento.

Termos de indexação: Reabsorção radicular. Dente decíduo. Extração dentária.

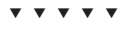

1 Universidade Estadual de Campinas, Faculdade de Odontologia de Piracicaba, Departamento de Odontopediatria. Av. Limeira, 901, Areião, 13414-903, Piracicaba, SP, Brasil. Correspondence to: RM PUPPIN-RONTANI1 E-mail: <rmpuppin@unicamp.br>.

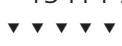

Borgo GO, Sousa KG, Moreira KMS, Puppin-Rontani RM. A minimally invasive technique for primary tooth extraction: a case report. RGO, Rev Gaúch Odontol. 2021;69:e20210020. http://dx.doi.org/10.1590/1981-86372021002020190153 


\section{INTRODUCTION}

Root resorption is characterized by the loss of cementum and / or dentin from the tooth root as a result of internal or external odontoclastic action [1]. The sites where root resorption occurs indicate the nature of the condition and the appropriate therapeutic approach for each case $[2,3]$.

External root resorption (ERR) usually occurs in the cervical portion of the root, developing from an injury to the periodontal ligament and the subepithelial cementum [4]. In later stages, ERR may also involve the pulp tissues [5, 6]. More recently, ERR diagnosis has become easier with the improvement of radiographic techniques combined with Cone Beam Computer Tomography (CBCT) [7, 8], which has been considered the best approach to diagnose root resorption lesions. The ERR treatment depends on the severity and location of the lesions as well as on the possibility of restoring the affected site(s). Although there is no consensus in the scientific literature about the best clinical management of root resorption [9], it is important to consider that the residual dental structure should be able to self-restore and self-preserve. Small lesions have the most favorable outcome, especially if there is no pulp involvement. These lesions can be restored using a direct technique with glass ionomer cement or composite resin $[10,11]$. While teeth affected by small lesions with pulp involvement can be restored following endodontic treatment, those with extensive and inaccessible lesions have a worse prognosis and, therefore, are indicated for extraction [10].

Root resorption of deciduous teeth is an expected physiological reaction when driven by the eruption of the underlying permanent teeth, which is known as the exfoliation process [12]. In contrast, pathological root resorption may take place due to the following reasons: 1) Excessive and constant forces during facial growth and muscle maturation, in that the chewing muscles exert forces greater than what the periodontal ligament of deciduous teeth can support $[13,14]$. This fact can cause the weakening and consequent necrosis of the periodontal ligament and ultimately result in tooth resorption; 2) Occlusal alteration during the mixed dentition phase, where a permanent tooth of one arch occludes improperly with a deciduous tooth on the other arch, again producing forces greater than the supportive tissue response [15]; 3) Local trauma involving the oral cavity, which may result in internal or external root resorption, regardless of the treatment performed after the trauma [16]; 4) ERR caused by the eruption of the underlying permanent teeth, which occurs due to the physical contact between the crown of the non-erupted tooth and the root of the deciduous tooth [17].

The extraction of teeth with a damaged structure (e.g., resorbed root surfaces) should ideally cause minor alveolar bone expansion. In addition, it requires gentle separation of the periodontal ligament and simple coronal extraction of the tooth to avoid any excessive forces that might produce root and alveolar bone fractures $[18,19]$. This caution is usually required in dental implant surgery, in which it is essential to use appropriate and specialized equipment to perform atraumatic tooth extraction. Among the devices used in atraumatic surgery is the periotome. This instrument breaks apart the fibers of the periodontal ligament before tooth extraction, thereby reducing the tissue trauma and maintaining the soft and hard tissue architecture, which is important to prevent root fracture [20]. Since this technique is not commonly used in pediatric dentistry, the aim of this case report was to show the usefulness of the periotome for extraction of deciduous teeth due to premature cervical root resorption.

\section{CASE REPORT}

A systemically healthy 8-year-old boy presented to the Piracicaba Dental School (University of Campinas, São Paulo, Brazil) to receive conventional dental care in the pediatric dentistry department. Extra- and intra-oral examination revealed no signs of disease. The patient did not complain of any pain or discomfort, nor had any active carious lesions. His legal guardian complaint was of a slight crowding in the anterior region of maxilla and mandible.

Panoramic radiographic imaging and plaster casting of both arches were requested for orthodontic planning. The panoramic radiograph, however, revealed four radiolucent lesions on the mesial faces of the roots of the maxillary right and left deciduous canines (teeth \#53 and \#63, respectively) and mandibular right and left deciduous canines (teeth $\# 73$ and 83, respectively). All lesions were located on the cervical area, indicating external cervical resorption (ECR) with pulp exposure. This same radiograph showed a slight distalization of the germs of the mandibular right and left second premolars (teeth \#35 and \#45, respectively), possibly interfering in the exfoliation of the mesial roots of the mandibular right and 
left deciduous molars (teeth \#75 and \#85, respectively), as shown in figure 1.

The teeth showing ECR were extracted in this case because of the subgingival location of the lesions and their broad extension, which were not only unsuitable for restoration but could also pose a high risk of root fracture in the future. A minimally invasive extraction technique was used herein with the periotome device (figure 2).

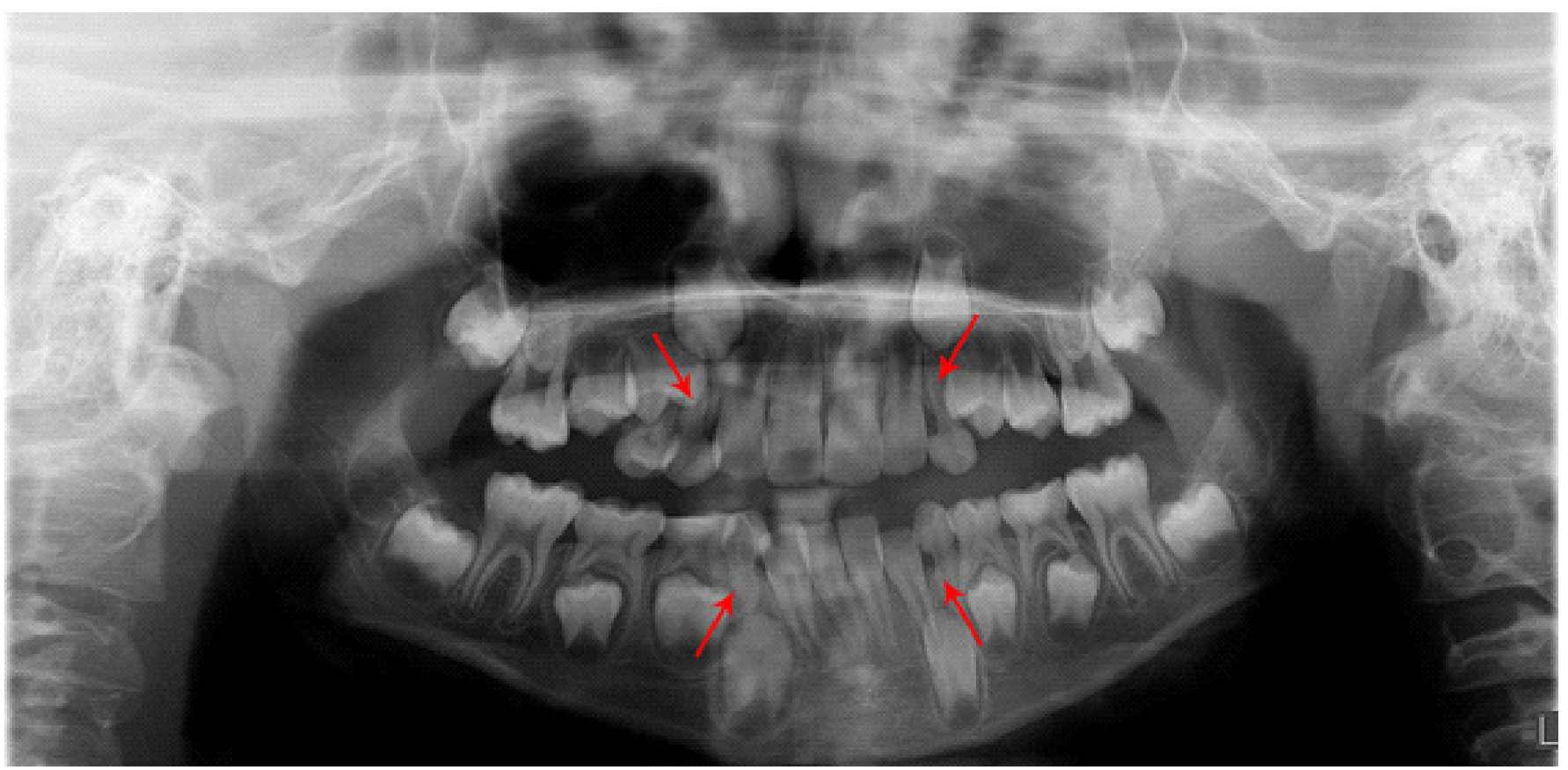

Figure 1. Panoramic radiograph showing external root resorption (red arrow) of the mesial face of the maxillary and mandibular right and left deciduous canines (teeth \#53, \#63, \#73 and \#83).

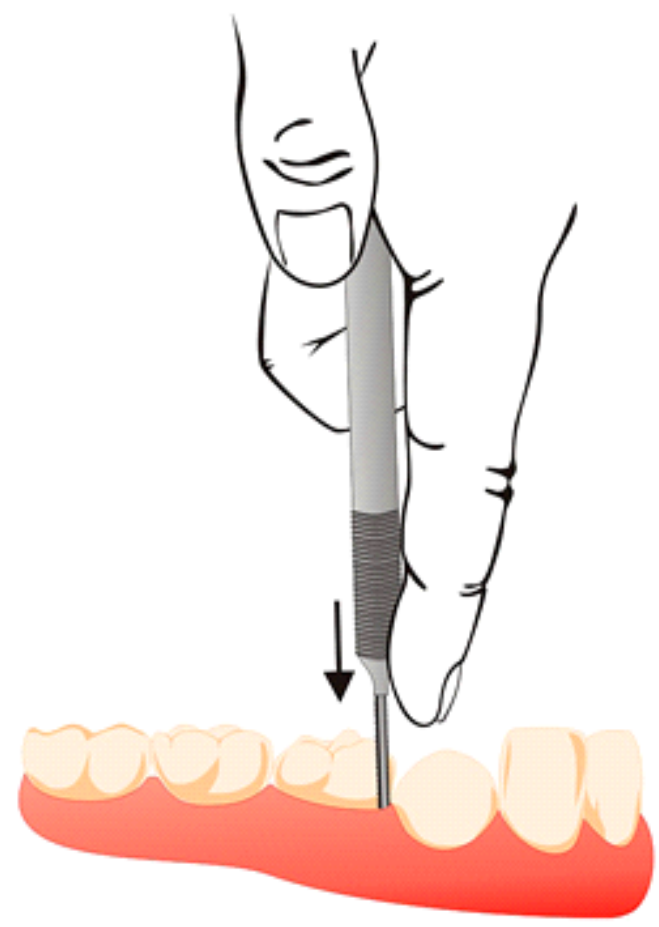

Figure 2. Tooth extraction using the periotome device.

\section{DISCUSSION}

Tooth extraction may be defined as a painless removal of the tooth with minimal tissue trauma, ideally with a painless and edema-free postoperative period [21]. The conventional forceps technique can be considered a traumatic approach, because it uses forceps to grip the tooth under manual pressure. Depending on how extraction forces are applied, there may be an increased risk of tooth fracture, and the whole surgical procedure can be compromised [22]. To overcome these issues, the periotome has been designed for tooth extraction before implant surgery to break apart the fibers of the periodontal ligament without causing damage to adjacent tissues, to prevent alveolar bone expansion and to provide a simple coronal extraction of the tooth [18, 19]. Atraumatic dental extraction nearly reaches these expectations since it preserves the bone and gingival architecture during exodontia [18, 23, 24].

The periotome was shown to maintain the hard and soft tissue architecture, since it acts removing the 
tooth without damaging the surrounding alveolar bone, especially in complex cases such as those involving crown fracture. The technique consists of tooth removal without the need of making a flap, thereby avoiding the unnecessary exposure of the bone and also reducing the chances of root fracture during the procedure [20,25].

The use of the periotome should be considered in pediatric dentistry as it increases patient's comfort and reduces the trauma against fragile dental structures. Herein, the patient presented minor pain and no postoperative edema, corroborating with what is described in the literature $[25,26]$. Moreover, the procedure length was reduced and there was a cleaner operative gap with little bleeding as compared to the conventional technique (figure 3).

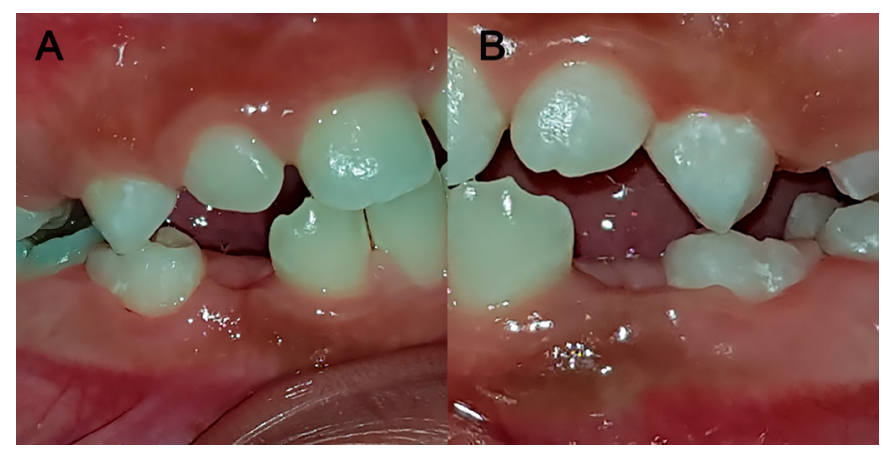

Figure 3. Seven-day postoperative view following extraction of the (A) mandibular right deciduous canine (tooth \#83) using the periotome device; and extraction of the (B) mandibular left deciduous canine (tooth \#73) using conventional forceps.

Lastly, the patient's mother reported that the patient had to use pain control medication and showed edema following tooth extraction using the conventional technique. In contrast, less discomfort, no swelling or complaints were reported after tooth extraction with the periotome device.

\section{CONCLUSION}

The periotome device showed to be an alternative to improve pediatric surgery due to better patient behavior and healing, and reduced procedure length. This technique should be considered for patient comfort and safety.

\section{Collaborators}

GO BORGO performed the surgery and wrote the article. KG SOUSA, assisted the surgery and wrote the article. KMS MOREIRA, assisted the surgery and wrote the article and RM PUPPIN-RONTANI, professor responsible for the clinical case and wrote the article. All authors contributed equally to the achievement of this case report.

\section{REFERENCES}

1. Patel $S$, Kanagasingam $S$, Pitt Ford T. External cervical resorption: a review. J Endod. 2009;35(5):616-25. http://dx.doi. org/10.1016/j.joen.2009.01.015

2. Patel S, Ford TP. Is the resorption external or internal? Dent Update. 2007;34(4):218-20, 222, 224-6, 229. http://dx.doi. org/10.12968/denu.2007.34.4.218

3. Patel $\mathrm{S}$, Saberi $\mathrm{N}$. The ins and outs of root resorption. $\mathrm{Br}$ Dent J. 2018;224(9):691-699. http://dx.doi.org/10.1038/ sj.bdj.2018.352

4. Andreasen JO, Andreasen FM. Textbook and color atlas of traumatic injuries to the teeth. 4th edn. Copenhagen: Munksgaard; 2007. p. 1358-81.

5. Luso S, Luder HU. Resorption pattern and radiographic diagnosis of invasive cervical resorption. A correlative micro-CT, scanning electron and light microscopic evaluation of a case series. Schweiz Monatsschr Zahnmed. 2012;122(10):914-30.

6. Mavridou AM, Hauben E, Wevers M, Schepers E, Bergmans L, Lambrechts P. Understanding external cervical tooth resorption in vital teeth. J Endod. $2016 ; 42(12): 1737-1751$. http://dx.doi.org/10.1016/j.joen.2016.06.007

7. PatelS, Dawood A, Ford TP, Whaites E. The potential applications of cone beam computed tomography in the management of endodontic problems. Int Endod J. 2007;40(10):818-30. http:// dx.doi.org/10.1111/j.1365-2591.2007.01299.x

8. Durack C, Patel S, Davies J, Wilson R, Mannocci F. Diagnostic accuracy of small volume cone beam computed tomography and intraoral periapical radiography for the detection of simulated external inflammatory root resorption. Int Endod J. 2011;44(2):136-47. http://dx.doi.org/10.1111/1.13652591.2010.01819.x

9. Patel S, Foschi F, Condon R, Pimentel T, Bhuva B. External cervical resorption-part 2: Management. Int Endod J. 2018;51(11):1224-1238. http://dx.doi.org/ 10.1111/iej.12946

10. Heithersay GS. Management of tooth resorption. Aust Dent J. 2007;52(1 Suppl):S105-21. http://dx.doi. org/10.1111/j.1834-7819.2007.tb00519.x

11. Trope M. Root Resorption due to Dental Trauma. Endod Topics. 2002;1(1):79-100. http://dx.doi.org/10.1034/j.16011546.2002.10106.x

12. Kronfeld R. The resorption of the roots of deciduous teeth. Pedodonti. 1932;46-49.

13. Avery JK. Oral development and histology. 3rd ed. Thieme: New York; 2002. p. 134-140. 
14. Andreasen JO, Andreasen FM. Textbook and color atlas of traumatic injuries to the teeth. 3rd ed. Munksgaard: Copenhagen; 1994. p. 95-102.

15. Obersztyn A. Experimental investigation of factors causing resorption of deciduous teeth. J Dent Res. 1963;42:660-74. http://dx.doi.org/10.1177/00220345630420021401

16. Cho WC, Nam OH, Kim MS, Lee HS, Choi SC. A retrospective study of traumatic dental injuries in primary dentition: treatment outcomes of splinting. Acta Odontol Scand. 2018;76(4):253-256. http://dx.doi.org/10.1080/00016357.2 017.1414956

17. Ericson S, Bjerklin K, Falahat B. Does the canine dental follicle cause resorption of permanent incisor roots? A computed tomographic study of erupting maxillary canines. Angle Orthod. 2002;72(2):95-104. http://dx.doi.org/10.1043/00033219(2002)072<0095:DTCDFC>2.0.CO;2

18. Dym H, Weiss A. Exodontia: tips and techniques for better outcomes. Dent Clin North Am. 2012;56(1):245-66, x. http:// dx.doi.org/10.1016/j.cden.2011.07.002

19. Weiss A, Stern A, Dym H. Technological advances in extraction techniques and outpatient oral surgery. Dent Clin North Am. 2011;55(3):501-13, viii. http://dx.doi.org/10.1016/j. cden.2011.02.008
20. Levitt D. Atraumatic extraction and root retrieval using the periotome: a precursor to immediate placement of dental implants. Dent Today. 2001;20(11):53-7.

21. Howe GL. Some complications of tooth extraction. Ann R Coll Surg Engl. 1962;30:309-23.

22. Misch CE, Perez HM. Atraumatic extractions: a biomechanical rationale. Dent Today. 2008;27(8):98, 100-1.

23. Saund D, Dietrich T. Minimally-invasive toothextraction: doorknobs and strings revisited! Dent Update. 2013 May;40(4):325-6, 32830. http://dx.doi.org/10.12968/denu.2013.40.4.325

24. Kosinski T. Use of innovative physics forceps for extractions in preparation for dental implants. Implant News. 2012;14(2):1-9.

25. Sharma SD, Vidya B, Alexander M, Deshmukh S. Periotome as an Aid to Atraumatic Extraction: A Comparative Double Blind Randomized Controlled Trial. J Maxillofac Oral Surg. 2015;14(3):611-5. http://dx. doi.org/10.1007/s12663-014-0723-8

26. Hargreaves K, Abbott PV. Drugs for pain management in dentistry. Aust Dent J. 2005;50(4 Suppl 2):S14-22. https://doi. org/10.1111/j.1834-7819.2005.tb00378.x

Received on: 3/11/2019 Approved on: 12/2/2020 